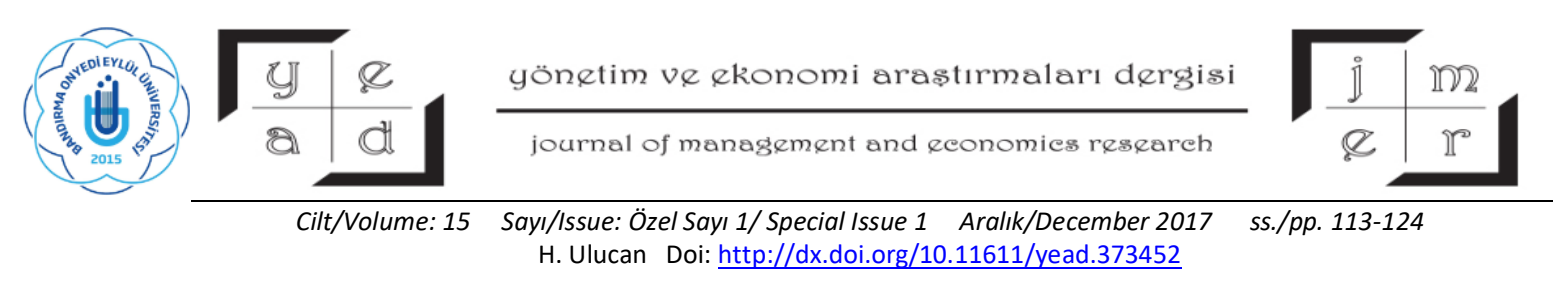

\title{
DOMESTIC VIOLENCE AND FEMALE'S LABOR MARKET CONDITIONS IN TURKEY: AN ANALYSIS OF CROSS SECTIONAL DATA ${ }^{1}$
}

\section{Asst. Prof. Hakan ULUCAN*}

\begin{abstract}
The main objective of this study is to find out and present the economic factors behind the problem of spousal violence against women. Two models, simple and extended, are estimated by linear regression model and Logit. Main finding is the negative relationship between the spousal violence and education level of the women. Education seems as the most effective way for the Turkish woman to get away from violence. Violence is lower on the women in more secure work conditions, indicating that the labor market conditions are also important. The labor market status of the women matters more than their husbands, indicating that empowerment of the women is one of the key issues to fight with domestic violence. Alcohol usage of husband seems another essential factor increasing the violence against females.
\end{abstract}

Key Words: Domestic Violence against Women, Cross Sectional Data, Household Bargaining Model JEL Classification: J12, J16, C21

\section{AİLE İÇİ ŞİDDET VE KADININ İŞGÜCÜ PİYASA KOŞULLARI: BİR YATAY KESİT VERİ ANALİí}

ÖZ

Bu çalışmanın ana amacı kadınlara yönelik eşten kaynaklanan şiddetin arkasındaki ekonomik faktörleri bulmaktır. Basit ve genişletilmiş iki model doğrusal ve logit modeli kullanarak tahmin edilmişstir. Ana bulgu eş kaynaklı şiddet ile eğitim arasındaki negatif ilişkidir. Eğitim kadınlar için eş kaynaklı şiddetten kaçınmanın en verimli yolu olarak gözükmektedir. İsgücü piyasa şartlarının da önemini gösterir bir şekilde, daha güvenli bir işte çalışan kadınlara yönelik şiddet daha düşüktür. Kadınların işgücü piyasasındaki durumu eşlerinin durumundan daha önemlidir. Bu kadınların

\footnotetext{
${ }^{1}$ The first draft of this paper is presented ICOAEF 2017 conferance on 06-07 December 2017

* Author. Assistant professor, Pamukkale University, Department of Economics, mail: hulucan@pau.edu.tr, phone: $+902582963866$
} 
Yönetim ve Ekonomi Araștırmaları Dergisi / Journal of Management and Economics Research

Cilt/Volume: 15 Sayı/Issue: Özel Sayı 1/Special Issue 1 Aralık/December 2017 ss./pp. 113-124

H. Ulucan Doi: http://dx.doi.org/10.11611/yead.373452

güçlendirilmesinin aile içi şiddetle mücadelede anahtar konu olduğunu göstermektedir. Eşin alkol kullanımı kadınlar üzerindeki şiddet konusunda diğer bir önemli faktördür.

Anahtar Kelimeler: Kadınlara Yönelik Aile İçi Şiddet, Yatay Kesit Verisi, Hanehalkı Pazarlık Modeli Jel Sinıflandırması: J12, J16, C21

\section{INTRODUCTION}

One of the most important problem of the Turkish economy is the low rate of female labor force participation. This means that Turkish economy is not able to use its half of the population effectively. This problem has many sides. When the factors that deepen this problem are analyzed, increasing violence rates attract the attention. Violence on females is not only a reason for low participation but also a reason for low productivity levels of females by leading to physical and psychological harm on the female population. Besides, it creates enormous costs to health sector. Unhealthy generations growing up under severe family environments are another part of problem caused by domestic violence.

The problem has been getting worse during the last decades. Turkey is a country which aims to overcome middle income trap. However, the standards of developed countries have not been cached up yet. Dual structures may have deepen the problem. One side of the country tries to catch up standards of developed countries. The other sides have not been able to get rid of underdevelopment. These underdeveloped structures remain traditions that overvalues man over woman. The females are stuck between these two structures. They have to work to fight with poverty faced by their families. On the other hand, their participation creates a disturbance in some parts of the society. This disturbance may be reflected in the behaviors of their husbands. It is impossible to fix the problems related with women in the labor market as long as this contradiction remains.

The main objectives of this study are to find out and present the economic factors behind the underlined problem of spousal violence against women, and to draw some policy implications to solve or ease the problem. Main finding is the negative relationship between the spousal violence and education level of the women. It seems that education is the most effective way for the Turkish woman to get away from violence. Violence is lower on the women in more secure work conditions, indicating that the labor market conditions are also important. Alcohol usage of husband seems another essential factor increasing the violence against females.

The study is organized as follows. In the next section, the literature is analyzed. Then, theories on spousal violence against women are presented in the third section. The characteristics of the data 
Yönetim ve Ekonomi Araștırmaları Dergisi / Journal of Management and Economics Research

Cilt/Volume: 15 Sayı/Issue: Özel Sayı 1/Special Issue 1 Aralık/December 2017 ss./pp. 113-124

H. Ulucan Doi: http://dx.doi.org/10.11611/yead.373452

set used in the study and descriptive statistics are presented in the fourth section. In the fifth section, estimation model and results are presented. Finally, the study ends with conclusion.

\section{LITERATURE REVIEW}

Aizer (2010), in her inspirational study, studies the relationship between the domestic violence against women and their labor market conditions by using the exogenous variations in the labor demand for the women in the California. Aizer suggests that potential labor market conditions matter instead of actual conditions. Thus, probability on violence can even decrease for housewives if labor market conditions improve. As being consistent with this argument, estimations reveal that employment and earnings reduce the violence on women. Relative labor market conditions of women as shown by the gender wage gap also play key role in reduction of violence against women.

Macmillan and Gartner (1999) study the violence against Canadian women by using multinomial logistic regression model. Their major finding is that the labor market status of a woman should be evaluated with labor market status of her husband. The effect of the status of the woman on violence depends on the labor force status of her husband. They suggests that the employment of the woman can reduce the risk of spousal violence when her husband is also employed. However, the employment of the woman can increase the risk of violence if her husband is unemployed. This finding of Macmillan and Gartner is in parallel with the arguments of male backlash theory. They argue that cultural factors play important role in violence.

Chin (2011) studies the relationship between the violence and labor force participation of women in India by using the exogenous variations in labor demand in rural areas. Some rural areas in India concentrate on the rise production while some areas concentrates on wheat production. Rise growing areas depend on rainfalls. The labor demand for females increases when rainfalls in rice areas increases. Using the variations in demand for female labor, Chin reveals that an increase in employment of the women reduces the incidence of violence in India. Two effects are in progress in India, the male backlash and exposure reduction. The former is dominated by the latter when there is an increase in the employment levels of the women in India. Chin suggests that household bargaining models cannot explain the characteristics of violence in India.

Benson et al. (2003) suggests that the rate of violence is higher in the poorer neighborhoods. It is also higher in the families under economic stress according to their study on violence in the USA. They also use the logistic regression in the study.

Keskin and Erten (2016) show that, as a result of the participation increase of the women caused by compulsory education law, psychological violence on Turkish women has increased in their study 
Yönetim ve Ekonomi Araștırmaları Dergisi / Journal of Management and Economics Research

Cilt/Volume: 15 Sayı/Issue: Özel Sayı 1/Special Issue 1 Aralık/December 2017 ss./pp. 113-124

H. Ulucan Doi: http://dx.doi.org/10.11611/yead.373452

using regression discontinuity design. The pressure to extract some amount of their income has also increased. These findings are in consistent with male backlash theories and financial extraction theories discussed in the next section.

\section{THEORY}

The connection between violence against women and their labor market conditions are explained by various theoretical models developed by economists, criminologists, and sociologists.

The household bargaining model of economics on this issue underlines the negative relationship between labor market conditions of women and domestic violence against them. Aizer (2010) shows that the husband has a utility function which is increasing in his violence against his wife. On the other hand, utility of wife is decreasing in the violence that she face. Aizer argues that when labor market conditions of women improves the outside options of the women will be improved according to the model. This will enable the wife to exit from marriage if the violence on her exceeds a certain level.

The male backlash theory based on anthropology and sociology suggests that the relationship between labor market conditions of women and the spousal violence on them is positive. Males are willing to play traditional leader role in their families. As a result, they evaluate the improved role of their wives in labor market as a threat to their traditional role. Then, they tend to use violence against them. This mechanism is still in progress especially in some developing countries (Chin, 2012). The incidents that can be explained by this theory is higher in the developing countries because traditional structures which lose their importance with the capitalist development are more powerful in developing countries. Traditional interpretations of religions can also open way to domestic violence because they emphasize the traditional role of males in families.

Exposure reduction theory developed by criminologists suggests that improving labor market conditions affect the domestic violence negatively because the amount of time spent with husband decreases as labor market conditions improve (Aizer 2010). The less amount of time spent with the husband means the less amount of violence for the wife (Chin 2012).

Financial extraction theory suggests that husbands use violence against their wives in order to extract some amount of financial assets of them (Chin, 2012). Therefore the relationship is positive. The improved labor market conditions increase the amount of financial assets of the women, increasing spousal violence on them.

Resource deprivation effect, on the other hand, explains the relationship by emphasizing the effect of stress level which is higher in poorer families on domestic violence. Therefore, the relationship 
Yönetim ve Ekonomi Araștırmaları Dergisi / Journal of Management and Economics Research

Cilt/Volume: 15 Sayı/Issue: Özel Sayı 1/Special Issue 1 Aralık/December 2017 ss./pp. 113-124

H. Ulucan Doi: http://dx.doi.org/10.11611/yead.373452

between violence and labor market conditions is positive. Economic conditions become worse as labor market conditions get worse, increasing the stress in the family. This stress results in the increase in the violence (Fox et al., 2002).

It should be noted that all these theories can be useful at the same time even in the same country even in the same family. Household bargaining models can explain some trends in middle class families while some incidents in more traditional and underdeveloped regions can be interpreted by male backlash theory. The employment of wife can increase her bargaining power in the family, and decrease the amount of time that she spent with her husband, validating household bargaining models and exposure reduction theory at the same time. Therefore the key issue is not the superiority of one model on the others. A researcher should specify which incident can be explained by which theory or which parts of the society behaves consistently with which theory.

\section{DATA AND DESCRIPTIVE STATISTICS}

The National Research on Domestic Violence against Women in Turkey Micro Data Set of 2014 is used in this study. The data set is designed by Turkstat, and covers about 8000 women who were interviewed in a face to face manner from about 15000 households. The data presents characteristics of the interviewed woman and her husband. The education level and labor force status of the couples are presented in the data set.

Firstly a dummy variable is constructed for the females who faced with sexual, physical or both types of partner violence in the last 12 months. Table 1 summarizes the basic indicators of the violence on woman caused by their partners in Turkey. The share of the women faced with violence by her partner is 32.2 percent, indicating the seriousness of the problem in the country. 24.4 percent of total female population is faced with physical violence while 11.1 percent is exposed to sexual assault. 3.3 percent is exposed to both types of violence.

Table 1. Basic Indicators on Violence

\begin{tabular}{lcc}
\hline \hline \multicolumn{1}{c}{ Some Indicators on Violence } & & Percentage \\
\hline \hline $\begin{array}{l}\text { The Share of the Women Violated from their } \\
\text { Partners.. } \\
\text { The Share of the Women who are not Violated from }\end{array}$ & 32.2 \\
their Partners & 67.8 \\
$\begin{array}{l}\text { The Share of the Women faced with Physical } \\
\text { violence } \\
\text { The Share of the Women faced with Sexual }\end{array}$ & 24.4 \\
$\begin{array}{l}\text { Assault } \\
\text { The Share of the Women faced with both Physical } \\
\text { and Sexual Assault }\end{array}$ & 11.1 \\
\hline \hline
\end{tabular}


Yönetim ve Ekonomi Araștırmaları Dergisi / Journal of Management and Economics Research Cilt/Volume: 15 Sayı/Issue: Özel Sayı 1/Special Issue 1 Aralık/December 2017 ss./pp. 113-124 H. Ulucan Doi: http://dx.doi.org/10.11611/yead.373452

Table 2 below represents some basic indicators of the women who are violated by their partners and the others. The first group of variables shows education levels. The education level is lower in the violated women as shown in Table 2 . The primary school graduates is 15 percent higher in the violated women. High school graduates in the violated women is lower by about 11 percent than the women who are not violated. The difference is about 10 percent for the university graduates. These differences clearly show that there are significant differences in the education level between violated and other women.

Second group of the variables in Table 2 shows the employment of the violated women and others in Turkey. There is a small difference between violated women and others in terms of the employment. 23 percent of the violated women is employed while this share is 21.3 percent in the rest.

Table 2. Comparison between Women Violated by Their Partners and the Others in terms of Education, Employment, and Power on Their Own Income

\begin{tabular}{|c|c|c|}
\hline Education Level & Violated & Not Violated \\
\hline Without a degree & 14.13 & 9.77 \\
\hline Primary school & 52.6 & 37.5 \\
\hline Middle School & 12.83 & 11.07 \\
\hline High School & 13.36 & 24.63 \\
\hline University & 6.36 & 15.83 \\
\hline Master Degree & 0.51 & 1.00 \\
\hline Doctorate Degree & 0.05 & 0.22 \\
\hline Employment & Violated & Not Violated \\
\hline The Share of the Women who are employed & 22.59 & 21.32 \\
\hline The Share of the Women Who are not employed & 77.41 & 78.68 \\
\hline Some Labor Market Indicators of Violated Women & Violated & Not Violated \\
\hline $\begin{array}{l}\text { The Share of the Women who are able to spend all of their income } \\
\text { freely }\end{array}$ & 20.8 & 21.9 \\
\hline $\begin{array}{l}\text { The Share of the Women who are forced to give some amount of } \\
\text { their income }\end{array}$ & 3.6 & 2.2 \\
\hline The Share of the Women who are forced to give all of their income & 2.3 & 1.6 \\
\hline
\end{tabular}


Yönetim ve Ekonomi Araștırmaları Dergisi / Journal of Management and Economics Research

Cilt/Volume: 15 Sayı/Issue: Özel Sayı 1/Special Issue 1 Aralık/December 2017 ss./pp. 113-124

H. Ulucan Doi: http://dx.doi.org/10.11611/yead.373452

The Share of Women Without a level of income

73.3

74.3

The third group of the variables in Table 2 shows the relative power of violated women on their income to the others. The share of women who are able to spend her money by themselves is 20.8 percent in the violated. This share is 21.9 percent in the women who are not violated. The share of women who are forced to give some amount of money to their husband or family is 3.6 percent in the violated women while this share is 2.2 percent in the women who are not violated. The women who are forced to give all the money they earn is again higher in the violated women as expected. The indicators on the power of the Turkish women on their earnings show that violated women has less power on their income than the rest. This can validate financial extraction theories suggesting that violence can be caused by the husband who wants to extract some or all amount of financial assets owned by his wife.

\section{ESTIMATION}

In estimation, only married women are focused. The others are excluded from the estimation. Two models, a simple and an extended, are estimated by linear regression model and Logit. In the simple model, only educational dummies are included in order to see the effect of education on the incidence of violence. Then, the model is extended by adding the labor force variables of the wife and her husband, and the alcohol usage of the husband, into model in addition to educational dummies.

The Equation 1 below shows the equation estimated in the study. $V$ shows whether the woman is violated physically in the last 12 months of their marriage. $W$ shows the characteristics of the wife and $H$ shows the characteristics of her husband. Two estimations are conducted in this study. The first model includes only the education levels of wife and husband. In the extended estimation, the labor force statuses of the wife and husband are added to the model. Besides, the alcohol consumption dummy for the husband is also included in the extended estimation. Alcohol dummy shows whether the husband uses alcohol, at least, one or two times a week.

$$
V_{i}=\alpha W_{i}+\beta H_{i}+\varepsilon_{i}
$$

Table 3 shows the results of the simple model. The estimation results are generally consistent with the theories. The education parameters show the effect of corresponding level relatively to those without a degree. The most of educational dummies are negative and significant for the women confirming the household bargaining models suggesting the improvement in potential labor market conditions of the females reduce the probability of the violence on them. The education is the most important factor increasing the potential labor market conditions of women. Education starts to reduce 
Yönetim ve Ekonomi Araștırmaları Dergisi / Journal of Management and Economics Research Cilt/Volume: 15 Sayı/Issue: Özel Sayı 1/Special Issue 1 Aralık/December 2017 ss./pp. 113-124 H. Ulucan Doi: http://dx.doi.org/10.11611/yead.373452

the probability of violence significantly with the threshold of high school degree in Turkey. The effects of education levels under high school have no significant effect on the violence. Women needs at least a high school degree to decrease the probability of spousal violence. This can be due to the fact that the female labor under high school level are in similar conditions in the labor market. The negative effect of education level keeps increasing until doctorate level. The effect of doctorate level is insignificant. This may be due to the role of exposure effect. Doctorate level means higher productivity levels, and so lower work hours increasing the time of exposure to the husband. Then, the household bargaining effect may have been dominated by exposure increase. Finally, the parameter may have lost significance between two opposite effects.

Table 3. Estimation Results

\begin{tabular}{|c|c|c|}
\hline Variables & Linear Regression & Logit \\
\hline \multirow[t]{2}{*}{ Primary school } & 0.009 & 0.04 \\
\hline & $(0.02)$ & $(0.09)$ \\
\hline \multirow[t]{2}{*}{ Middle School } & 0.02 & 0.09 \\
\hline & $(0.02)$ & $(0.13)$ \\
\hline \multirow[t]{2}{*}{ High School } & $-0.08 * * *$ & $-0.39 * * *$ \\
\hline & $(0.02)$ & $(0.13)$ \\
\hline \multirow[t]{2}{*}{ University } & $-0.11 * * *$ & $-0.58 * * *$ \\
\hline & $(0.03)$ & $(0.18)$ \\
\hline \multirow[t]{2}{*}{ Master Degree } & $-0.15^{*}$ & -0.89 \\
\hline & $(0.08)$ & $(0.63)$ \\
\hline \multirow[t]{2}{*}{ Doc. Degree } & -0.14 & -0.78 \\
\hline & $(0.19)$ & $(1.21)$ \\
\hline \multirow[t]{2}{*}{ Husband Primary School } & -0.03 & -0.15 \\
\hline & $(0.04)$ & $(0.19)$ \\
\hline \multirow[t]{2}{*}{ Husband Middle School } & -0.07 & -0.29 \\
\hline & $(0.04)$ & $(0.20)$ \\
\hline \multirow[t]{2}{*}{ Husband High School } & $-0.13 * * *$ & $-0.56 * * *$ \\
\hline & $(0.04)$ & $(0.20)$ \\
\hline \multirow[t]{2}{*}{ Husband University } & $-0.17 * * *$ & $-0.80 * * *$ \\
\hline & $(0.04)$ & $(0.22)$ \\
\hline \multirow[t]{2}{*}{ Husband Master } & $-0.23 * * *$ & $-1.22 * *$ \\
\hline & $(0.08)$ & $(0.61)$ \\
\hline \multirow[t]{2}{*}{ Husband Doctorate } & -0.12 & -0.50 \\
\hline & $(0.15)$ & $(0.89)$ \\
\hline
\end{tabular}

Notes: The numbers in the parenthesis represent standard errors. $* * *, * *, *$ shows the significance of corresponding parameter at $1 \%, 5 \%$ and $10 \%$ levels respectively.

The education level of the husband matters in similar way. Violence on the wife goes down as the education level of the husband increase. The education level of the husband starts to decrease the probability of violence against her wife with high school level. This finding is also similar to the findings on the education level of the women. The sizes of the parameters of the husband's education level are also close to those of the wife's education. There are several possible explanations for the negative relationship between the education level of the husband and the violence on his wife. An 
Yönetim ve Ekonomi Araștırmaları Dergisi / Journal of Management and Economics Research

Cilt/Volume: 15 Sayı/Issue: Özel Sayı 1/Special Issue 1 Aralık/December 2017 ss./pp. 113-124

H. Ulucan Doi: http://dx.doi.org/10.11611/yead.373452

educated man generally marry with an educated woman whose bargaining power is high in the marriage. Thus, violence is lower in the marriage according to household bargaining models. Another explanation is that education reduces violence by increasing the consciousness of the husband. One another is that the income level of a family with an educated husband is probably higher. Then, the economic conditions in the family are not stressful, decreasing the probability of violence.

Table 4 shows the results of the extended model in which some labor market variables and a dummy for alcohol usage of the husband is added to the model. The results on education is similar to the simple model. The dummies of labor force statuses show the impact of corresponding status relative to the women who are unemployed or out of labor force. In the results of extended model, it should firstly be noted that the level of violence is negative and significant for employers in linear regression. This confirms again the household bargaining models. Employers constitute one of the most powerful categories in the labor force status. The negative and significant coefficient indicates that the probability of violence is lower for more powerful women in terms of labor force status. However this parameter becomes insignificant in logit estimation. The positive and significant coefficient of dummies of irregular self-employed and seasonal worker women show that violence is higher for the women in more unsecure work conditions. The coefficient of regular self-employment is also positive and significant.

The coefficient of alcohol shows that the probability of being violated is higher for a woman with a husband who uses alcohol at least 1-2 times a week. Flanzer (1993) suggests that alcohol increase the probability of violence in the family by reducing judgement and reasoning capability of users. The estimated coefficients of both linear regression and logit are consistent with Flanzer's arguments. Another impact of alcohol may be resource deprivation effect which can also be a factor increasing the risk of violence. The addicted husbands in the families spend some important amount of income to alcohol, then family can be deprived of essential goods. The ratio of the income spent on alcohol in total income of household can be higher in the lower income families with alcohol addicted members. Resource deprivation can increase the probability of violence by increasing the stress in the family. The effect of alcohol on the violence needs further detailed research. The possible effects discussed above can differ in socioeconomic groups. Interaction dummies of alcohol with education and income level of the family can be constructed to find out whether the effects of alcohol differs in socioeconomic groups in Turkey. 
Yönetim ve Ekonomi Arastırmaları Dergisi / Journal of Management and Economics Research Cilt/Volume: 15 Sayı/Issue: Özel Sayı 1/Special Issue 1 Aralık/December 2017 ss./pp. 113-124 H. Ulucan Doi: http://dx.doi.org/10.11611/yead.373452

Table 4. Estimation Results of the Extended Model

\begin{tabular}{|c|c|c|}
\hline Variables & Linear Regression & Logit \\
\hline \multirow[t]{2}{*}{ Primary school } & 0.009 & 0.02 \\
\hline & $(0.02)$ & $(0.10)$ \\
\hline \multirow[t]{2}{*}{ Middle School } & $\begin{array}{l}0.02 \\
(0.02)\end{array}$ & 0.10 \\
\hline & & \\
\hline High School & $\begin{array}{c}-0.08 * * * \\
(0.02)\end{array}$ & $\begin{array}{c}-0.41 * * * \\
(0.13)\end{array}$ \\
\hline \multirow[t]{2}{*}{ University } & $-0.11 * * *$ & $-0.62 * * *$ \\
\hline & $(0.03)$ & $(0.21)$ \\
\hline \multirow[t]{2}{*}{ Master Degree } & $-0.15^{*}$ & -0.91 \\
\hline & $(0.08)$ & $(0.62)$ \\
\hline \multirow[t]{2}{*}{ Doc. Degree } & -0.15 & -0.81 \\
\hline & $(0.19)$ & $(1.27)$ \\
\hline \multirow[t]{2}{*}{ Husband Primary School } & -0.03 & -0.15 \\
\hline & $(0.04)$ & $(0.19)$ \\
\hline \multirow[t]{2}{*}{ Husband Middle School } & -0.07 & -0.29 \\
\hline & $(0.04)$ & $(0.20)$ \\
\hline \multirow[t]{2}{*}{ Husband High School } & $-0.12 * * *$ & $-0.53 * * *$ \\
\hline & $(0.04)$ & $(0.20)$ \\
\hline \multirow[t]{2}{*}{ Husband University } & $-0.16 * * *$ & $-0.75 * * *$ \\
\hline & $(0.04)$ & $(0.23)$ \\
\hline \multirow[t]{2}{*}{ Husband Master } & $-0.20 * * *$ & $-1.13^{*}$ \\
\hline & $(0.08)$ & $(0.61)$ \\
\hline \multirow[t]{2}{*}{ Husband Doctorate } & -0.05 & -0.16 \\
\hline & $(0.15)$ & $(0.89)$ \\
\hline \multirow{2}{*}{ Employer } & $-0.16^{*}$ & -0.86 \\
\hline & $(0.04)$ & $(0.65)$ \\
\hline \multirow[t]{2}{*}{ Permanent Worker } & -0.004 & -0.02 \\
\hline & $(0.023)$ & $(0.14)$ \\
\hline \multirow[t]{2}{*}{ Salaried Officer } & 0.006 & 0.01 \\
\hline & $(0.03)$ & $(0.26)$ \\
\hline \multirow[t]{2}{*}{ Seasonal Worker } & $0.10 * * *$ & $0.44 * *$ \\
\hline & $(0.03)$ & $(0.18)$ \\
\hline \multirow[t]{2}{*}{ Self Employed (regular) } & $0.07 *$ & $0.31 *$ \\
\hline & $(0.03)$ & $(0.18)$ \\
\hline \multirow[t]{2}{*}{ Self Employed (irregular) } & $0.06 * *$ & $0.27 * *$ \\
\hline & $(0.02)$ & $(0.14)$ \\
\hline \multirow[t]{2}{*}{ Unpaid Family Worker } & 0.02 & 0.10 \\
\hline & 0.02 & $(0.11)$ \\
\hline \multirow[t]{2}{*}{ Husband Employer } & 0.01 & 0.07 \\
\hline & $(\mathbf{0 . 0 2})$ & $(\mathbf{0 . 1 5})$ \\
\hline \multirow[t]{2}{*}{ Husband Permanent Worker } & -0.02 & -0.11 \\
\hline & $(0.01)$ & $(0.09)$ \\
\hline Husband Salaried Officer & -0.03 & -0.17 \\
\hline & $(0.02)$ & $(0.15)$ \\
\hline Husband Seasonal Worker & -0.03 & -0.15 \\
\hline & $(0.02)$ & $(0.13)$ \\
\hline Husband Self Employed (regular) & -0.03 & -0.13 \\
\hline & $(0.02)$ & $(0.12)$ \\
\hline Husband Self Employed (irregular) & 0.04 & -0.17 \\
\hline & $(0.02)$ & $(0.15)$ \\
\hline Husband Unpaid Family Worker & 0.05 & 0.21 \\
\hline & $(0.06)$ & $(0.26)$ \\
\hline Husband Alcohol & $0.20 * * *$ & $0.89 * * *$ \\
\hline & $(0.02)$ & $(0.13$ \\
\hline
\end{tabular}

Notes: The numbers in the parenthesis represent standard errrors. ***, **,* shows the significance of corresponding parameter at $1 \%, 5 \%$ and $10 \%$ levels respectively 
Yönetim ve Ekonomi Araștırmaları Dergisi / Journal of Management and Economics Research

Cilt/Volume: 15 Sayı/Issue: Özel Sayı 1/Special Issue 1 Aralık/December 2017 ss./pp. 113-124

H. Ulucan Doi: http://dx.doi.org/10.11611/yead.373452

\section{CONCLUSION}

This study shows that the education is the most important factor that can decrease the domestic violence level in Turkey. The education levels of both women and men are important. Then, the increasing participation of the women in higher education in the last decades due to the higher education expansion can be evaluated as a hopeful development. However, the country still needs important progress as shown by the statistics on the domestic violence level in the country. The labor market status of the women matters more than men, indicating that empowerment of the women is one of the key issues to fight with domestic violence. Alcohol addiction of the husband is another factor increasing the probability of violence. Violence incidents caused by alcohol remain high despite high alcohol prices in the country. This means that other measures than price increase of alcohol can be introduced to fight with alcohol related violence incidences in the country. These measures can be education and health programs to fight with alcohol addiction. Otherwise, if high price of alcohol is seen as only tool, violence can increase in the families with alcohol addicted husbands due to economic deprivation of the family caused by high alcohol prices.

This study also calls for future researches on the violence. The effects of absolute conditions of the wife and her husband are analyzed in the study. The impact of relative conditions can also be analyzed in a future study. Poverty of the family is not included in the models due to data difficulties. The ways to include poverty into model can be thought by future researchers. The price effect on alcohol consumption and the effect of alcohol on violence can differ in different sub-groups. These effects related with alcohol can be analyzed separately for the various groups by future researchers.

\section{REFERENCES}

Aizer, A. (2010). "The gender wage gap and domestic violence." The American economic review, 100(4), 1847.

Benson, M. L., Fox, G. L., DeMaris, A., \& Van Wyk, J. (2003). "Neighborhood disadvantage, individual economic distress and violence against women in intimate relationships." Journal of quantitative criminology, 19(3), 207-235.

Chin, Y. M. (2012). “Male backlash, bargaining, or exposure reduction?: women's working status and physical spousal violence in India.” Journal of population Economics, 25(1), 175-200.

Erten, B., \& Keskin, P. (2016). "For Better or for Worse?: Education and the Prevalence of Domestic Violence in Turkey.” American Economic Journal: Applied Economics. 
Flanzer, J. P. (1993). "Alcohol and other drugs are key causal agents of violence." Current controversies on family violence, 171-181.

Fox, G. L., Benson, M. L., DeMaris, A. A., \& Wyk, J. (2002). “Economic distress and intimate violence: Testing family stress and resources theories." Journal of Marriage and Family, 64(3), 793-807.

Macmillan, R., \& Gartner, R. (1999). "When she brings home the bacon: Labor-force participation and the risk of spousal violence against women." Journal of Marriage and the Family, 947-958. 